\title{
Surgical Correction of Penoscrotal Web: A Case Series With Literature Review
}

\author{
Penoskrotal Perdenin Cerrahi Onarımı: \\ Olgu Serisi ve Literatür Değerlendirilmesi
}

\section{Olgu Sunumu} Case Report
Received/Geliş: 01.11.2019 Accepted/Kabul: 16.12.2019

Published Online: 05.01.2021

Volkan Sarper Erikci Sağlık Bilimleri Üniversitesi, Tepecik SUAM, Çocuk Cerrahisi Anabilim Dalı, İzmir - Türkiye

verikci@yahoo.com ORCID: 0000-0002-9384-2578

Cite as: Erikci VS. Surgical correction of penoscrotal web: A case series with literature review. Tepecik Eğit. ve Araşt. Hast. Dergisi. 2020;30(3):302-6.

\section{Volkan Sarper Erikci ๑}

\section{ABSTRACT}

Penoscrotal webbing (PSW) is a penile anomaly involving penile and scrotal skin. There are various surgical techniques for repairing PSW with different terminologies. Herein we present our surgical experience of Z-plasty procedure in these cases.

Five patients with an average age of 46 months who were diagnosed and under follow-up for PSW, between June 2017 and May 2019 were included in this retrospective study. Along with demographic and clinical characteristics, treatment and follow-up records were evaluated

Isolated PSW was observed in 4 patients and one patient had an associated megameatus intact prepuce (MMIP) of a hypospadias variant in addition to PSW. Circumcision and ventral prepuce reconstruction of the penis with the aid of "Z-plasty" sufficiently solved problem and acceptable postoperative results were obtained.

PSW is a condition that warrants surgical treatment. During the management of these children, in the case suggestive of penile skin abnormality at the time of circumcision, circumcision should be deferred and the case should be consulted to a pediatric surgeon or a pediatric urologist. Gentle surgical treatment is recommended for a favourable surgical and psychological result.

Keywords: Children, penoscrotal web, surgery

ÖZ

Penoskrotal perde penil ve skrotal deriyi içeren penis anomalisidir. Bu anomalinin tedavisine ilişkin değişik terminolojiler altında tanımlanan çeşitli cerrahi onarım teknikleri mevcuttur. Bu çalışmada bu olgulardaki Z-plasti tekniğine ilişkin cerrahi tecrübemiz sunulmaktadır.

Bu retrospektif çalışmaya Haziran 2017 ile Mayıs 2019 tarihleri arasında penoskrotal perde tanısı ortalama yaş 46 ay olan 5 olgu dahil edilmiştir. Bu olgulardaki demografi ve klinik özelliklerin yanında tedavi ve izlem bulguları değerlendirilmiştir.

izole penoskrotal perde 4 olguda görülmüş, bir olguda da bu anomaliye eşlik eden hipospadias çeşidi olan megameatus intakt prepisyum saptanmıştır. Olgularımızda sünnet ve Z-plasti tekniği kullanılarak yapılan penisin ventral prepisyum rekonstrüksiyonu problemi çözmede yeterli bulunmuş ve kabul edilebilir postoperatif sonuçlar elde edilmiştir.

Penoskrotal perde cerrahi onarım gerektiren bir anomalidir. Bu olguların yönetiminde sünnet sırasında penoskrotal perdeyi düşündüren penil deri anomalisi saptanırsa sünnet ertelenmeli ve derhal çocuk cerrahisi ya da çocuk ürolojisi konsültasyonu istenmelidir. Tatminkar cerrahi ve psikolojik sonuç için nazik bir cerrahi girişim önerilmektedir.

Anahtar kelimeler: Çocuklar, penoskrotal perde, cerrahi

\section{INTRODUCTION}

\section{Keyes first described PSW and sugges-} ted that this anomaly existed when penis lacked its suitable sheath of skin and lied embedded in different sites such as under the skin of the abdo- men, thigh or scrotal area (1). This entity poses significant problems both to patients and to clinicians dealing with this problem ${ }^{(1)}$. Later on, in 1977, PSW was further defined as complete or partial PSW ${ }^{(2)}$. The proximal part of the penis becomes embedded under (c) Telif hakkı T.C. Sağık Bakanlı̆ı̆ı İmir Tepecik Eğit. ve Araşt. Hastanesi. Logos Tıp Yayıncılık tarafindan yayınlanmaktadır. Bu dergide yayınlanan bütün makaleler Creative Commons Attf-GayriTicari 4.0 Uluslararası Lisansı ile lisanslanmıştır.

(c) Copyright Association of Publication of the T.C. Ministry of Health izmir Tepecik Education and Research Hospital. This journal published by Logos Medical Publishing. Licenced by Creative Commons Attribution-NonCommercial 4.0 International (CC BY) 
cutaneous tissue in patients with partial type of this disease while, the penis is completely concealed and the prepuce covers the glans penis in children with complete type of PSW.

As a penile and scrotal skin abnormality, PSW is accepted as a penile disease and the spectrum of buried penis involves this entity. Another description of this entity is the invasion of scrotal skin towards ventral site of the penile shaft and it has been suggested that abnormal dartos bands obscure the penoscrotal angle ${ }^{(3)}$. This abnormal genital appearance usually seen in these children is the reason for anxiety in children, and their families. Pain, abnormal stream of urine or genital dysfunction have also been reported ${ }^{(4)}$. Various surgical techniques have been proposed for PSW with different terminologies ${ }^{(5-8)}$. Herein we present 5 children with PSW treated using Z-plasty and this issue together with the surgical treatment of PSW is discussed under the light of relevant literature.

\section{MATERIAL and METHOD}

Pediatric patients who were diagnosed and followed up for PSW, between June 2017 and May 2019 were included in this retrospective study. Along with demographic and clinical characteristics, treatment and follow-up records were collected. In all patients, the diagnosis of PSW was confirmed by physical examination. Circumcision and ventral prepuce reconstruction of the penis with the aid of "Z-plasty" solved

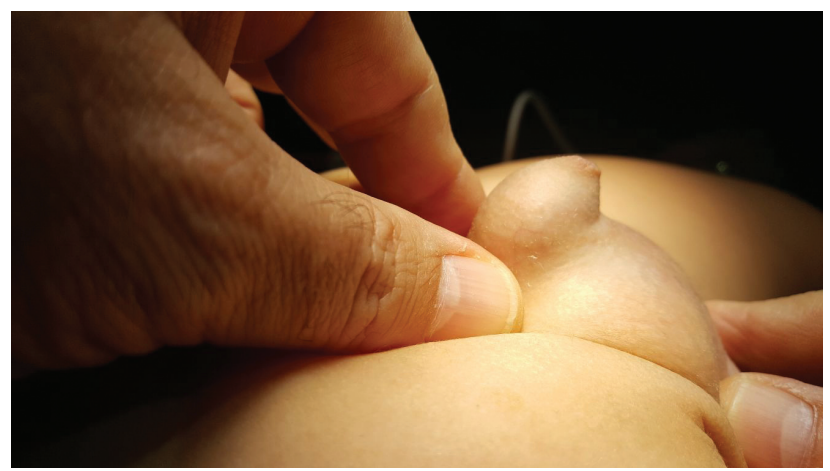

Figure 1. A child with penoscrotal web. problem in 4 of these cases with isolated PSW (Figures 1, 2). In addition to Z-plasty, glanular approximation procedure including construction of the neourethra using subcuticular and uninterrupted $7 / 0$ polydioxanone (PDS ${ }^{\circledR}$ ) sutures was performed in the child who had associated MMIP in addition to PSW (Figures 3,4$)$. In this patient, any wound infection or disruption, an improper urine flow and unsatisfactory glanular appearance were not observed.

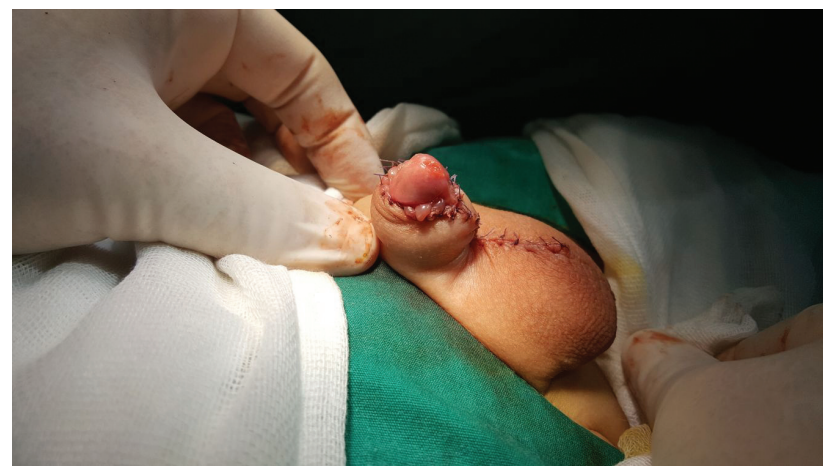

Figure 2. Immediate postoperative view after completion of circumcision and Z-plasty.

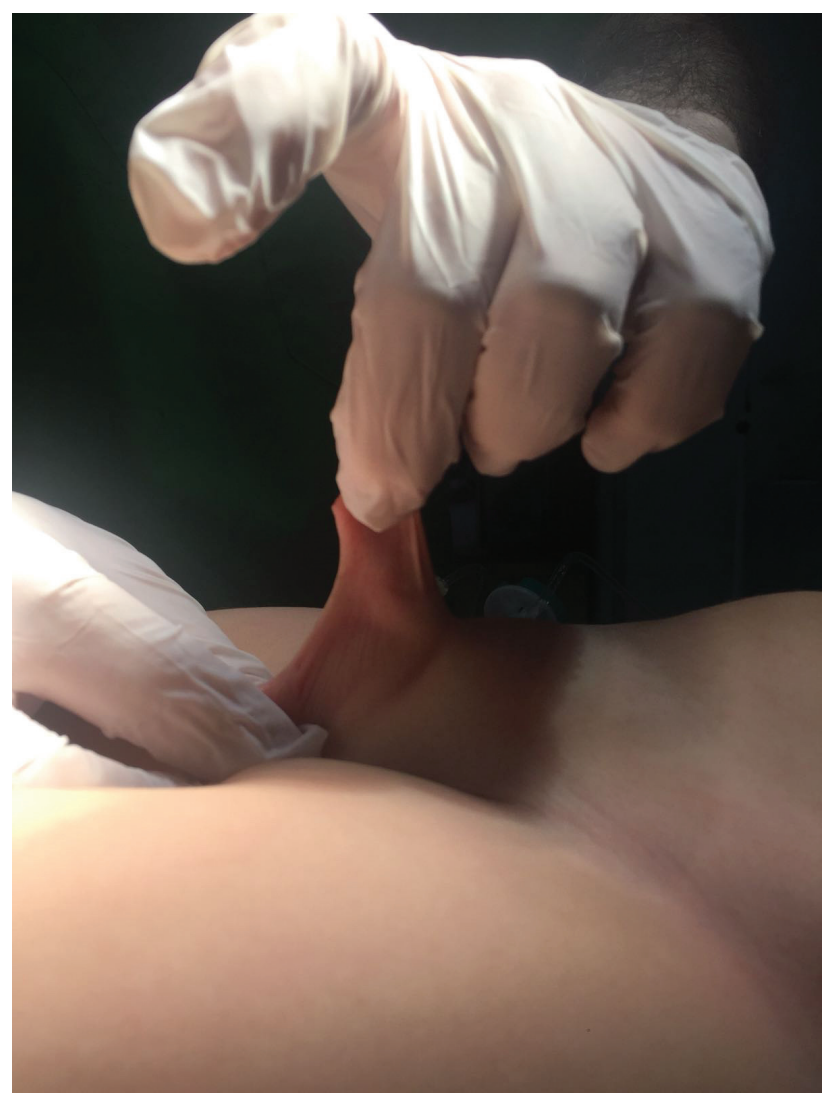

Figure 3. Preoperative view of a child with MMIP in addition to PSW. 


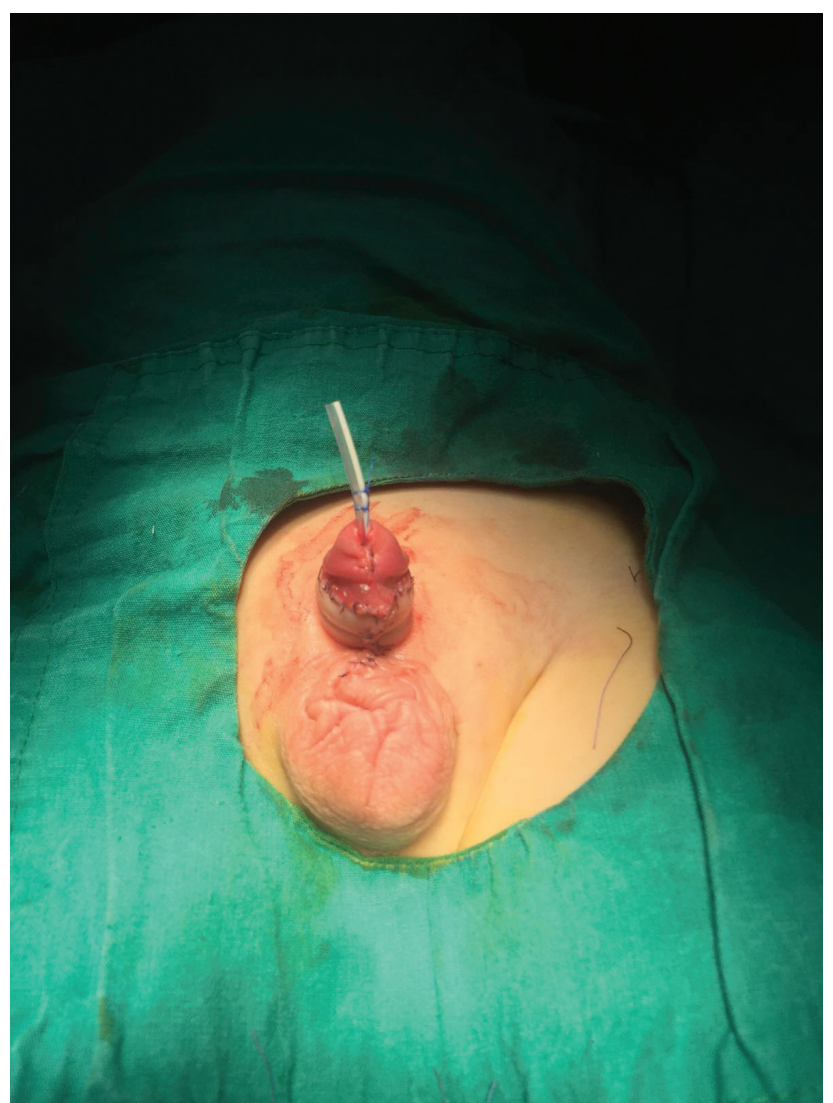

Figure 4. Postoperative ventral view of the penis after Z-plasty combined with glanular approximation technique.

The study was carried out in compliance with the 1964 Helsinki Declaration and was approved by the ethical committee of Tepecik Training Hospital, and the written consent from the families or the legal representatives of the cases were taken.

\section{RESULTS}

Five patients were diagnosed as PSW during the study period. The median age of the patients at the time of diagnosis was 46 months (18-90 months). The mean duration of follow-up was 17.2 months (4-27 months). Isolated PSW was observed in 4 patients and one patient had an associated megameatus intact prepuce (MMIP) of a hypospadias variant in addition to PSW. All of these patients were otherwise normal and the medical history did not reveal local infection, urinary retention or chronic urinary dripping in any of them. But there was parental anxi- ety due to the feeling that their child's penis was extremely short. Circumcision and Z-plasty, solved the problem in all of these cases. In this series there was no complication related to the procedure itself and no need for a secondary surgical intervention after an unsuccessful Z-plasty. With an uneventful postoperative period, the families of the children were happy for their childrens' penile lengths and appearances.

\section{DISCUSSION}

When the penis remains hidden and embedded under the suprapubic area this condition is called as buried penis ${ }^{\left({ }^{9}\right)}$. In this disease, penis is completely or partially absent depending on the degree of anomaly. The true prevalance of this condition is not known exactly and the condition usually causes distress when circumcision is planned to be performed.

There is an interchanceable terminology on this issue and Maizels et al. ${ }^{(10)}$ in 1986 offered a classification including a "buried penis" with excess suprapubic fat, "webbed penis" involving scrotal skin having a hidden angle between penis and scrotum, "trapped penis" with penile shaft is encastered in the pubic fat either due to trauma or excess circumcision that diminishes penile skin, "micropenis" in which the penile length smaller than two standard deviations below average and "diminutive penis" in which the penis is small due to epispadias/exstrophy, severe hypospadias, etc. Despite these studies, there is no universal concensus on the exact definition of buried penis.

The general accepted theory for PSW is the migration of scrotal skin towards the ventral area of penis (11). With a loss of penoscrotal angle, PSW may cause sexual problems during the later adult life of these children. It may also cause psychological trauma due to abnormal penile appearance ${ }^{(12)}$. Although there may not be any advantages in daily clinical practice, Koutby and El Gohary suggested a classifying system 
which included seven subgroups of PSW ${ }^{(12)}$. Parents of children with PSW are usually anxious due to their feeling that their child's penis is extremely short with regard to child's age. Some cases may present with pain, abnormal stream of urine, local infection, urinary retention and undirected voiding. Associated urethral pathologies like hypospadias are extremely rare in these children and only one patient in this series had an associated hypospadias variant of MMIP and he was successfully treated using glanular approximation procedure in addition to Z-plasty for PSW. Fortunately except for cosmetic problem, the presented children in this report did not have urinary symptoms due to PSW.

Several surgical techniques have been proposed in the surgical management of these children ${ }^{(5-8)}$. These are incision of web transversely and closing vertically, Z-plasty at the penoscrotal junction and penoplasty ${ }^{(11)}$, double-V scrotoplasty ${ }^{(3)}$. Excision of excess fat is another choice of surgical management of PSW but this method is largely reserved for adult patients ${ }^{(12)}$. The main aims of surgical treatment are; to have exposure of the glans and coronal sulcus, to have a penile skin length equal to the penile shaft length, to achieve a straight penis and to get a normal penoscrotal angle ${ }^{(13)}$. Most of the less severe webbings can be managed with circumcision alone. Although there are numerous techniques that have been reported to correct severe PSW, whichever surgical technique is used, it is important to conserve adequate skin on the ventral aspect of the penis. Surgical treatment techniques in the management of PSW include Z-plasty procedures, turning flaps, reverse $Y$ and complete expansion of the penile shaft (14-19). What is common in all of these surgical techniques is to perform ventral skin lay over without fixing to the scrotum.

Z-plasty is a plastic surgery technique that is used to improve the functional and cosmetic appearance of scars. It is one of the treatment options in treating children with PSW. In this technique two triangular flaps of equal dimensions are created and then transposed (Figure 5). Basic Z-plasty flaps are created using angles of 30, 45 and 60 degrees on each side, which can elongate the penis for further $25 \%$, $50 \%$ and $75 \%$ of the former penile length, respectively. The length and angle of each flap must be precisely the same and this is key to avoiding mismatched flaps that may be difficult to close. Complications of Z-plasty include flap necrosis, hematoma formation under the flaps, wound infection, trapdoor effect, and sloughing of the flap caused by high wound site tension. The procedure usually involves skin and subcutaneous tissues and often there is no need to perform surgical intervention including the dartos layer for correction and reconstitution of the penoscrotal angle.

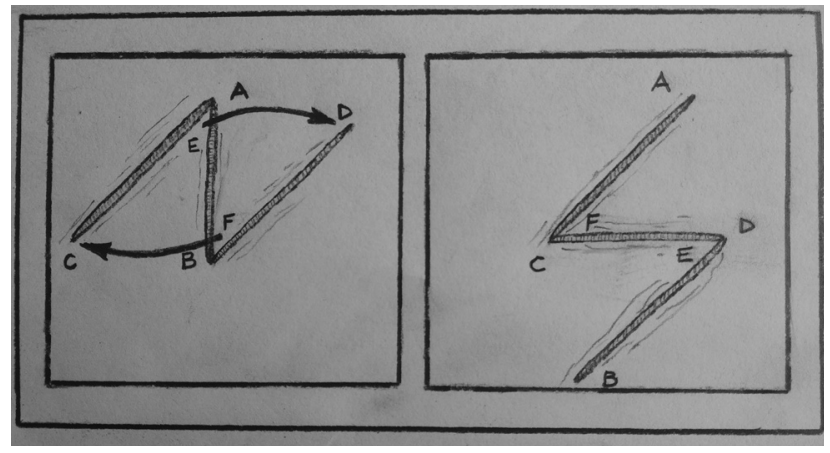

Figure 5: Details of Z-plasty technique. Incisions are made vertically and triangular flaps are prepared. Flap $F$ is pulled toward $C$ and flap $E$ toward $D$, the flaps $E$ and $F$ are transposed.

In addition to formal circumcision, Z-plasty technique was performed in our patients with satisfactory cosmetic results. Although there is no consensus on the timing of PSW correction, it has been reported that if significant PSW is detected on examination, reconstruction of PSW at 6-12 months has been recommended ${ }^{(3)}$. Unfortunately, patients with PSW in our series were older than 1 year and the youngest patient was 18 months old. This may be explained by the rather delayed referral of these children to our clinic. Nevertheless in the management of these cases, it is important to perform reconstructive surgery for PSW before the achievement of gender identity. 
In conclusion, PSW is a condition that warrants surgical treatment. If there is a suspicion of penile skin abnormality at the time of circumcision, circumcision should be deferred and the patient should be consulted to a pediatric surgeon. Both physical and psychological aspects of PSW have enormous significance. A timely Z-plasty is one of the surgical treatment options for PSW with a favourable result.

\section{Conflict of Interest: None.}

Informed Consent: Has been received from the parent of the patient.

\section{REFERENCES}

1. Keyes EL. Phimosis-Paraphimosis-Tumors of the penis. Appleton\&Co., New York, NY, USA, 1919.

2. Crawford BS. Buried penis. Br J Plast Surg. 1977;30:96-9. [CrossRef]

3. McLeod DJ, Alpert SA. Double-V scrotoplasty for repair of congenital penoscrotal webbing: a hidden scar technique. J Pediatr Urol. 2014;10:810-4. [CrossRef]

4. Perlmutter AD, Chamberlain JW. Webbed penis without chordee. J Urol. 1972;107:320-1. [CrossRef]

5. Wollin M, Duffy G, Malone PS, Ransley PG. Buried penis: a novel approach. Br J Urol. 1990;65:97-100. [CrossRef]

6. Brisson P, Patel H, Chan M, Feins N. Penoplasty for buried penies: J Pediatr Surg. 2001;36:421-5. [CrossRef]
7. Dilly AV, Currie BG. Webbed penis. Pediatr Surg Int. 1999;15:447-8. [CrossRef]

8. Lee $\mathrm{T}$, Suh $\mathrm{H}$, Han J. Correcting congenital concealed penis: new pediatric surgical technique. Urology. 2005;65:789-92. [CrossRef]

9. Chan IHY, Wong KKY. Common urological problems in children: prepuce, phimosis, and buried penis. Hong Kong Med J. 2016;22(3):263-9. [CrossRef]

10. Maizels M, Zaontz M, Donovan J, Bushnick PN, Firlit CF. Surgical correction of the buried penis: descripition of a classification system and a technique to correct the disorder. J Urol. 1986;136:268-71. [CrossRef]

11. Alter GJ, Salgado CJ, Chim H. Aesthetic surgery of the male genitalia. Seminars Plast Surg. 2011;25(3):189-95. [CrossRef]

12. King ICC, Tahir A, Ramanathan C, Siddiqui H. Buried penis: evaluation of outcomes in children and adults, modification of a unified treatment algorithm, and review of the literature. ISRN Urology. 2013; Article ID 109349, 1-7. [CrossRef]

13. El-Koutby M, El-Gohary MA. Webbed penis: a new classification system. J Indian Assoc Pediatr Surg. 2010;15:50-2. [CrossRef]

14. Alter GJ. Correction of penoscrotal web. J Sex Med. 2007;4:844-7. [CrossRef]

15. Borsellino A, Spagnoli A, Vallasciani S, Martini L, Ferro F. Surgical approach to concealed penis: technical refinements and outcome. J Urol. 2007;69:1195-8. [CrossRef]

16. Chen $Y$, Ding $X$, Luo $C$, et al. A new plastic surgical technique for adult congenital webbed penis. J Zhejiang Univ Sci B. 2012;13:757-60. [CrossRef]

17. Glanz S. Adult congenital penile deformity. Case report. Plast Reconstr Surg. 1968;41:579-80.

18. Redman JF. Technique for the correction of penoscrotal fusion. J Urol. 1985;133:432-3. [CrossRef]

19. Zaontz MR. Surgical management of the concealed penis with a penoscrotal web. Dialog Pediatr Urol. 2006;28:8. 